\title{
The periplasmic modifier protein for methanol dehydrogenase in the methylotrophs Methylophilus methylotrophus and Paracoccus denitrificans
}

\author{
ANTHONY R. LONG and CHRISTOPHER ANTHONY* \\ Biochemistry Department, University of Southampton, Southampton SO9 3TU, UK
}

(Received 18 April 1991; revised 30 May 1991; accepted 1 July 1991)

\begin{abstract}
A modifier protein (M-protein), which increases the affinity of methanol dehydrogenase (MDH) for alcohols but decreases its affinity for formaldehyde, has been partially purified from Methylophilus methylotrophus and Paracoccus denitrificans. Analysis was complicated by non-protein factors in bacterial extracts that are able to mimic M-protein in one of its functions - that of increasing the activity of MDH with butane-1,3-diol in the dyelinked assay system. The $67 \mathrm{kDa}$ polypeptide, previously identified as a subunit of the M-protein, is an unrelated cytoplasmic protein. The M-protein is exclusively periplasmic and is a multimeric protein with subunits of $45 \mathrm{kDa}$. The M-protein is active in the 'physiological' assay system with the specific cytochrome $c$ electron acceptor for MDH, lowering its affinity for formaldehyde. It has its maximum effect when the ratio of M-protein:MDH is 1:5 but its concentration in the periplasm is much lower than $20 \%$ of that of MDH.
\end{abstract}

\section{Introduction}

Gram-negative methylotrophic bacteria oxidize methanol by way of three periplasmic proteins. These are the quinoprotein methanol dehydrogenase (MDH), its specific electron acceptor, cytochrome $c_{\mathrm{L}}$ and a typical class I cytochrome $c$ which is the electron donor to the membrane cytochrome oxidase (Anthony, 1982, 1986, 1988, 1990). In the dye-linked assay system using phenazine ethosulphate (PES) as an artificial electron acceptor MDH has a wide substrate specificity which includes formaldehyde (in the hydrated gem-diol form). Extracts of some methylotrophs contain a protein that is able to extend the substrate specificity of MDH. This modifier protein (M-protein) facilitates the oxidation of poor substrates, such as propane-1,2-diol or butane1,3-diol, by increasing their affinity for $\mathrm{MDH}$, thus preventing inhibition of MDH by PES (Bolbot \& Anthony, 1980; Ford et al., 1985). The M-protein was subsequently partially purified from a facultative methylotroph, Methylobacterium extorquens AM1, and from an obligate methylotroph, Methylophilus methylotrophus, and shown to be a dimer of two identical subunits of $67 \mathrm{kDa}$. Using this preparation it was shown that the M-protein has a second characteristic in the dye-

\footnotetext{
Abbreviations: MDH, methanol dehydrogenase; M-protein, modifier protein; PES, phenazine ethosulphate.
}

linked assay system - its ability to diminish the affinity of MDH for formaldehyde, thus decreasing the rate of oxidation of this substrate (Page \& Anthony, 1986). It was proposed that the $\mathrm{M}$-protein might therefore act as a regulator of formaldehyde oxidation in the periplasm of methylotrophs, preventing the wasteful oxidation of formaldehyde to formate.

This has raised a number of questions that form the subject matter of this paper. How widespread is the occurrence of $\mathbf{M}$-proteins in methylotrophs? Are the amounts of M-protein affected markedly by the conditions used for growth? What is the location of the $\mathrm{M}$-protein; is it located in the periplasmic space as it would need to be if its function is by way of interaction with MDH? Does the M-protein have an inhibitory effect on formaldehyde oxidation by $\mathrm{MDH}$ when assayed in the physiological assay with cytochrome $c_{\mathrm{L}}$ as electron acceptor?

\section{Methods}

Growth, breakage and fractionation of bacteria and spheroplasts. Methylophilus methylotrophus (NCIB 10515) was grown on methanol in batch culture or continuous culture, harvested and bacterial extracts prepared as previously described (Cross \& Anthony, 1980a, b). The strain of Paracoccus denitrificans used in this work was the Oxford strain (NCIB 8944); it was grown aerobically in batch culture on methanol as described by Long \& Anthony (1991). Organism 4025 was grown on methanol in $\mathrm{O}_{2}$-limited continuous culture $\left(D=0.15 \mathrm{~h}^{-1}\right)$ as described by Auton \& Anthony (1989). Preparation of spheroplasts and 
fractionation of batch-grown bacteria was as described by Jones $e t$ al. (1982) (M. methylotrophus), and Long \& Anthony (1991) (P. denitrificans)

Measurement of protein, cytochromes, oxidases and NAD+-linked dehydrogenases. Protein was determined by the method of Bradford (1976). Dehydrogenases for glucose 6-phosphate and 6-phosphogluconate were determined as described by Lawton \& Anthony (1985), and malate dehydrogenase was determined as described by Alefounder \& Ferguson (1981). Cytochromes were measured as described by Cross \& Anthony (1980b) and the $o$-type oxidase was determined as described by Chan \& Anthony (1991).

$S D S-P A G E$ and determination of molecular mass. These techniques were as described by Long \& Anthony (1991). Quantitative evaluation of gels after protein staining was as described by Ford et al. (1985).

Measurement of dye-linked methanol dehydrogenase activity. This polarographic assay, based on that of Anthony \& Zatman (1967), was done in an oxygen electrode $(2 \mathrm{ml}$ volume $)$ at $30^{\circ} \mathrm{C}$ at $\mathrm{pH} 9.0$ in $125 \mathrm{~mm}$-Tris/ $\mathrm{HCl}$ buffer containing methanol $(7.5 \mathrm{mM})$, activator $\left(22.5 \mathrm{mM}-\mathrm{NH}_{4} \mathrm{Cl}\right)$ and electron acceptor (0.5 mM-PES). The reaction was started by addition of PES. One unit of activity is defined as that amount which catalyses the consumption of $1 \mathrm{nmol} \mathrm{O}_{2} \mathrm{~min}^{-1}$.

Measurement of $M$-protein activity in the dye-linked $M D H$ assay system. For measurements with purified M-protein, and during its purification, activity was determined by measuring its ability to promote oxidation of butane-1,3-diol by methanol dehydrogenase in the polarographic, dye-linked assay described above. The reaction mixture contained 60 units of pure MDH and butane-1,3-diol $(10 \mathrm{mM}$ for proteins of $P$. denitrificans and $20 \mathrm{mM}$ for proteins of $\boldsymbol{M}$. methylotrophus and organism 4025). Using this substrate the rate of oxygen consumption was zero within $10 \mathrm{~min}$ of addition of PES. When M-protein was present, a constant rate of oxygen consumption occurred after $10 \mathrm{~min}$ which was proportional to the amount of $\mathbf{M}$ protein added. One unit of $\mathbf{M}$-protein is defined as that amount of $\mathbf{M}$ protein which promotes the reduction of $1 \mathrm{nmol} \mathrm{O}_{2} \mathrm{~min}^{-1}$ by MDH. In crude extracts $M$-protein was determined by the same method except that the concentrations of MDH were the same as those already present in the extracts. For the purposes of comparison, pure MDH was added to ensure that extracts being compared contained the same number of units of $\mathrm{MDH}$.

Measurement of methanol and formaldehyde oxidation by MDH of $P$. denitrificans in the cytochrome-linked assay system. Two systems were used, both of which couple reduction of the specific cytochrome $c$ electron acceptor to reduction of a large excess of horse heart cytochrome $c$ (obtained from Sigma). When it was necessary to measure appearance of formaldehyde during methanol oxidation, or disappearance of formaldehyde when this was the sole substrate, the system of Beardmore-Gray et al. (1983) was followed. Reaction mixtures $(3 \mathrm{ml})$ contained pure MDH $(2 \mu \mathrm{M})$, horse heart cytochrome $c$ $(500 \mu \mathrm{M})$ and methanol $(3 \mathrm{mM})$ or formaldehyde $(100 \mu \mathrm{M})$ in HEPES buffer $\left(20 \mathrm{mM}, \mathrm{pH} 7.5\right.$ at $\left.20^{\circ} \mathrm{C}\right)$. The reaction was started by addition of the $22 \mathrm{kDa}$ cytochrome $c_{552}(2 \mu \mathrm{M})$.

When it was necessary to do large numbers of assays for kinetic studies with small amounts of scarce proteins, the method of Day \& Anthony (1990) was used. The $1 \mathrm{ml}$ reaction mixture contained HEPES buffer $(12 \mathrm{mM}, \mathrm{pH} 7 \cdot 5)$, cytochrome $c_{552}(10 \mu \mathrm{M})$ and horse heart cytochrome $c(50 \mu \mathrm{M})$. Reactions were started by addition of MDH $(2 \mu \mathrm{M})$. Reduction of cytochrome $c$ was recorded at $550 \mathrm{~nm}$.

Purification of $M D H$ and $M$-protein of $M$. methylotrophus, and production of antibodies to $M$-protein. The proteins were purified from $\mathrm{O}_{2}$-limited bacteria grown on methanol at $D=0.15 \mathrm{~h}^{-1}$. MDH was purified as described by Beardmore-Gray et al. (1983) and M-protein as described by Page \& Anthony (1986). For production of antibodies Mprotein $(5 \mathrm{mg})$ was loaded on preparative scale SDS-PAGE gel prepared with $10 \%(\mathrm{w} / \mathrm{v})$ acrylamide $(14 \mathrm{~cm} \times 10 \mathrm{~cm} \times 6 \mathrm{~mm})$ and run at $40 \mathrm{~mA}$ for $16 \mathrm{~h}$. The gel was stained with $5 \%(\mathrm{w} / \mathrm{v})$ Coomassie Blue R-250 and the major band (about $67 \mathrm{kDa}$ ) was cut-out and electroeluted by the method of Walker (1982) to give $2.5 \mathrm{mg}$ protein; $150 \mu \mathrm{g}$ of this protein was then injected into each of two New Zealand White rabbits and each was boosted with $50 \mu \mathrm{g}$ protein 1 month later. Western blotting was done exactly as described by Day et al. (1990).

Partial purification of $M D H$ and $M$-protein from organism 4025. MDH was purified as described for $M$. methylotrophus by Beardmore-Gray et al. (1983). M-protein was purified as follows. Soluble extract $(2 \mathrm{~g}$ protein in $200 \mathrm{ml}$ ) was loaded on a column of DEAE-Sepharose $(8 \times 6 \mathrm{~cm})$ equilibrated in $20 \mathrm{~mm}$-HEPES buffer $(\mathrm{pH} 7.5)$. MDH, which did not adsorb to the column, was able to oxidize $10 \mathrm{~mm}$-butane1,3-diol in only a transient fashion indicating that an $\mathbf{M}$-protein had been separated from it and had adsorbed to the column. Protein was eluted by stepwise increases in $\mathrm{NaCl}$ concentration $(50,75,200$ and $400 \mathrm{~mm}$ ). The fractions able to inhibit formaldehyde oxidation by MDH were further purified by the method used for $M$-protein of $M$. methylotrophus (Page \& Anthony, 1986).

Partial purification of $M D H$, cytochrome $c_{552}$ and $M$-protein from $P$. denitrificans. $\mathrm{MDH}$ and cytochrome $c_{552}$ were purified as described by Long \& Anthony (1991). M-protein was purified as follows. Bovine DNAase I $(10 \mathrm{mg})$ was added to the periplasmic fraction $(5 \mathrm{l}$, containing $2 \mathrm{~g}$ protein), derived from $60 \mathrm{l}$ of bacterial culture. This was applied to a DEAE-Sepharose column $(12 \times 5 \mathrm{~cm})$ equilibrated in $20 \mathrm{mM}$-HEPES buffer (pH 7.5). Proteins were eluted with the same buffer containing stepwise increases in $\mathrm{NaCl}$ concentration $(50,100$ and $200 \mathrm{mM}$ ). The $\mathrm{M}$-protein was eluted with $200 \mathrm{mM}-\mathrm{NaCl}$, concentrated to $10 \mathrm{ml}$ over an Amicon YM-100 ultrafiltration membrane, and purified by gel-filtration on a column of Sephacryl S-200 $(85 \times 3.5 \mathrm{~cm})$ equilibrated in $20 \mathrm{~mm}-\mathrm{HEPES}$ buffer ( $\mathrm{pH} 7.5$ ) containing $100 \mathrm{~mm}$ $\mathrm{NaCl}$ (upward flow, $10 \mathrm{ml} \mathrm{h}^{-1}$ ). Active fractions were further purified by anion-exchange chromatography on a Pharmacia Mono-Q column ( $1 \mathrm{ml}$ ) equilibrated in the same buffer at a flow rate of $1 \mathrm{ml} \mathrm{min}-1$. A gradient of $0-500 \mathrm{mM}-\mathrm{NaCl}$ in $26 \mathrm{ml}$ buffer was used; M-protein was eluted with $200 \mathrm{~mm}-\mathrm{NaCl}$.

\section{Results}

\section{M-protein of Methylophilus methylotrophus}

Effect of growth conditions on production of M-protein in $M$. methylotrophus. The obligate methylotroph $M$. methylotrophus was grown in continuous culture at two different dilution rates and under two different nutrient limitations (Table 1). Under $\mathrm{O}_{2}$-limitation, when the dilution rate was increased 3-fold the M-protein activity decreased to $27 \%$ of the value recorded prior to the change in dilution rate, whereas the amount of $67 \mathrm{kDa}$ protein decreased to only $64 \%$. A similar (but less marked) result was obtained under methanol-limitation. When the nutrient limitation was changed from $\mathrm{O}_{2^{-}}$ limitation to carbon-limitation, at a fixed growth rate, the M-protein activity increased (by $34-85 \%$ ) whereas the amount of $67 \mathrm{kDa}$ protein decreased by about $20 \%$. These results are clearly not consistent with the previous 
Table 1. Effect of growth conditions on M-protein activity and synthesis of $67 \mathrm{kDa}$ protein in $\mathrm{M}$. methylotrophus

$M$. methylotrophus was grown in continuous culture and the soluble components of bacterial extracts run on SDS-PAGE to determine the amounts of $67 \mathrm{kDa}$ protein. This is expressed as the percentage of total protein present as determined by integration of scans of gels stained with Coomassie Blue. M-protein activity was measured as described in Methods.

\begin{tabular}{lccccc}
\hline \hline & \multicolumn{2}{c}{ Oxygen-limited bacteria } & & \multicolumn{2}{c}{ Methanol-limited bacteria } \\
\cline { 2 - 3 } \cline { 5 - 6 } & $\mu=0.05 \mathrm{~h}^{-1}$ & $\mu=0.15 \mathrm{~h}^{-1}$ & & $\mu=0.05 \mathrm{~h}^{-1}$ & $\mu=0.15 \mathrm{~h}^{-1}$ \\
\hline $\begin{array}{c}\text { M-protein activity } \\
\text { [units (mg protein) }\end{array}$ & 9.5 & 2.6 & & 12.7 & 4.8 \\
$\begin{array}{c}67 \mathrm{kDa} \text { polypeptide } \\
(\% \text { protein) }\end{array}$ & 8.7 & 5.6 & & 6.9 & 4.7 \\
\hline \hline
\end{tabular}

Table 2. Location of M-protein in M. methylotrophus and $P$. denitrificans

MDH activity was determined in the dye-linked assay system. Oxidase activity was determined using ascorbate/TMPD as substrate; this is a measure of the $\sigma$ type oxidase which contains cytochromes $b$ and $c$. M-protein activity was measured using butane-1,3-diol in the dye-linked assay system as described in Methods. MDH and the $67 \mathrm{kDa}$ protein were also measured on SDSpolyacrylamide gels after protein staining. ND, Not determined. (a) $M$. methylotrophus; (b) P. denitrificans.

\begin{tabular}{|c|c|c|c|c|c|c|}
\hline & \multicolumn{6}{|c|}{ Protein distribution $(\%)$} \\
\hline & \multicolumn{2}{|c|}{ Periplasm } & \multicolumn{2}{|c|}{ Cytoplasm } & \multicolumn{2}{|c|}{ Membranes } \\
\hline & (a) & (b) & (a) & (b) & (a) & (b) \\
\hline Glucose-6-phosphate dehydrogenase & 0 & ND & 88 & ND & 12 & ND \\
\hline 6-Phosphogluconate dehydrogenase & 0 & ND & 93 & ND & 7 & ND \\
\hline Malate dehydrogenase & ND & 3 & ND & 92 & ND & 5 \\
\hline Methanol dehydrogenase (activity) & 90 & 95 & 2 & 1 & 8 & 4 \\
\hline Methanol dehydrogenase (gel scan) & 81 & 89 & 3 & 1 & 16 & 10 \\
\hline Cytochrome $c$ & 76 & 70 & 3 & 2 & 21 & 28 \\
\hline Cytochrome $b$ & 0 & 0 & 0 & 0 & 100 & 100 \\
\hline Cytochrome $a$ & ND & 0 & ND & 0 & ND & 100 \\
\hline TMPD oxidase & 0 & ND & 0 & ND & 100 & ND \\
\hline $67 \mathrm{kDa}$ protein & 0 & ND & 78 & ND & 22 & ND \\
\hline M-protein activity & + & + & - & - & - & - \\
\hline
\end{tabular}

conclusion (Page \& Anthony, 1986) that the $67 \mathrm{kDa}$ protein catalyses $\mathrm{M}$-protein activity.

Localization of $M$-protein in $M$. methylotrophus. In order to investigate the location of the M-protein, and to consider further the relationship between the $67 \mathrm{kDa}$ protein and $\mathrm{M}$-protein activity, the active protein was purified as previously described (Page \& Anthony, 1986), and the $67 \mathrm{kDa}$ protein in the active fraction was eluted from an SDS-polyacrylamide gel and used to raise antibodies. These were then used to identify the location of the $67 \mathrm{kDa}$ protein and M-protein activity. Spheroplasts and periplasmic fractions were prepared, and the spheroplasts lysed and separated into cytoplasmic and membrane fractions. Table 2 shows that the dehydrogenases for glucose 6-phosphate and 6-phosphogluconate were predominantly in the cytoplasm and that MDH and cytochrome $c$ were mainly in the periplasmic fraction. Some of the cytochrome $c$ and all the cytochrome $b$ and cytochrome oxidase were in the membrane fraction. Western blotting, using antibody to the purified $67 \mathrm{kDa}$ protein, showed it to be present only in the cytoplasm and membrane; none was in the periplasmic fraction. By contrast, all the M-protein activity was in the periplasmic fraction where it needs to be in order to interact with the periplasmic MDH. These results suggested that the $67 \mathrm{kDa}$ protein is not the M-protein although it was the major protein in the active fractions after partial 
purification of M-protein from extracts prepared by sonication.

Purification of $M$-protein from $M$. methylotrophus. When purified from sonic extracts as previously described (Page \& Anthony, 1986), the major protein in active fractions was the $67 \mathrm{kDa}$ protein previously identified as the M-protein. However, further purification was achieved by anion-exchange chromatography on a Mono-Q column with a very shallow elution gradient (7 mM per $\mathrm{ml}$ ) (Fig. 1). This procedure completely separated the $67 \mathrm{kDa}$ protein from M-protein activity. SDS-PAGE of the pooled M-protein fractions showed that they contained at least three protein bands between 30 and $50 \mathrm{kDa}$. The active fractions contained no $67 \mathrm{kDa}$ protein and the $67 \mathrm{kDa}$ fractions had no $\mathrm{M}$ protein activity (data not shown).

Attempts at further purification of the M-protein were unsuccessful and this was investigated further using a second obligate methylotroph, organism 4025 .

\section{M-protein from organism 4025}

Organism 4025 is an obligate methylotroph, closely related to $M$. methylotrophus (Auton \& Anthony, 1989). After growth on methanol, crude extracts of this organism were able to stimulate the oxidation of butane1,3-diol indicating the presence of an M-protein and they

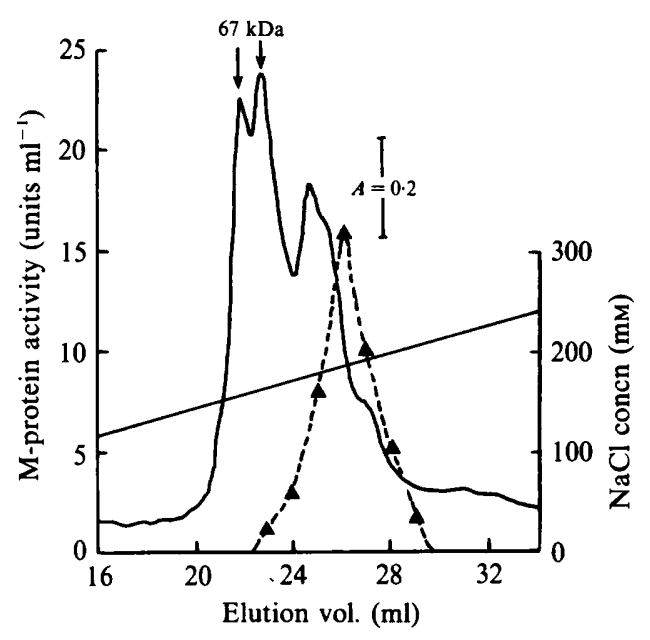

Fig. 1. Purification of $\mathrm{M}$-protein of $M$. methylotrophus by anionexchange chromatography. Fractions containing $M$-protein were eluted from a Mono- $Q$ column using a conventional gradient $(17 \mathrm{~mm}$ $\mathrm{NaCl} \mathrm{ml}{ }^{-1}$ ), desalted and $3.5 \mathrm{mg}$ protein applied to the same column equilibrated in $20 \mathrm{mM}$-HEPES buffer ( $\mathrm{pH} 7.5)$ and eluted as shown in this Figure with a shallow gradient of $\mathrm{NaCl}\left(7 \mathrm{mM}-\mathrm{NaCl} \mathrm{m}{ }^{-1}\right)$ (represented by a solid, sloping line). The solid curve represents protein, measured by its absorbance at $280 \mathrm{~nm}$ (the vertical bar represents an absorbance of 0.2 at this wavelength). All of the $67 \mathrm{kDa}$ protein eluted in the first major protein peak. $\Delta$, M-protein activity. contained a protein able to cross-react with antibody prepared against the presumed $(67 \mathrm{kDa}) \mathrm{M}$-protein of $M$. methylotrophus. After purification by the method used previously for $\boldsymbol{M}$. methylotrophus (Page \& Anthony, 1986), the active fractions showed one major band $(45 \mathrm{kDa})$ on SDS-PAGE plus four other proteins (data not shown). It contained no cross-reacting $67 \mathrm{kDa}$ protein and the fractions that did contain the $67 \mathrm{kDa}$ protein showed no $\mathbf{M}$-protein activity.

During the purification by stepwise elution from DEAE-cellulose, it was found that an unexpectedly high number of fractions were active in the normal $M$-protein assay stimulating oxidation of butane-1,3-diol. The periplasmic fractions were also able to inhibit the oxidation of formaldehyde, the activity that we consider to constitute the physiological activity of M-protein. It was subsequently shown that the activity of the 'apparent' M-protein fractions (which had no effect on formaldehyde oxidation) resided in compounds of low molecular mass (less than about $3 \mathrm{kDa}$ ). Furthermore, these compounds showed no activity of any sort in the physiological assay with cytochrome $c_{\mathrm{L}}$ as electron acceptor and alcohols or formaldehyde as substrate.

The results with the two obligate methylotrophs thus led to the same conclusion, that $\mathrm{M}$-protein activity is associated with a protein having subunits of $45 \mathrm{kDa}$, and that the $67 \mathrm{kDa}$ protein is not relevant to M-protein activity.

\section{M-protein of Paracoccus denitrificans}

This organism was used in this investigation as it is a markedly different sort of methylotroph from the obligate methylotrophs $M$. methylotrophus and organism 4025, and from the pink facultative methylotroph Methylobacterium extorquens AM1, in which M-protein was first described (Bolbot \& Anthony, 1980; Ford et al., 1985). $P$. denitrificans is a facultative methylotroph and autotroph that assimilates its cell carbon by way of $\mathrm{CO}_{2}$ and the Calvin cycle (Anthony, 1982). This is the organism first used for demonstration of the periplasmic location of MDH and for which methods are available for large-scale preparation of periplasmic fractions (Alefounder \& Ferguson, 1981; Long \& Anthony, 1991).

Location of $M$-protein in P. denitrificans. Preliminary investigations of extracts of methanol-grown bacteria demonstrated apparent M-protein activity in these fractions, and the results in Table 2 demonstrate that the M-protein activity of this methylotroph is also exclusively periplasmic; there was no activity in cytoplasmic or membrane fractions. However, because of the possibility that extracts might contain compounds demonstrating a 'false M-protein' activity as shown for organism 4025, it 


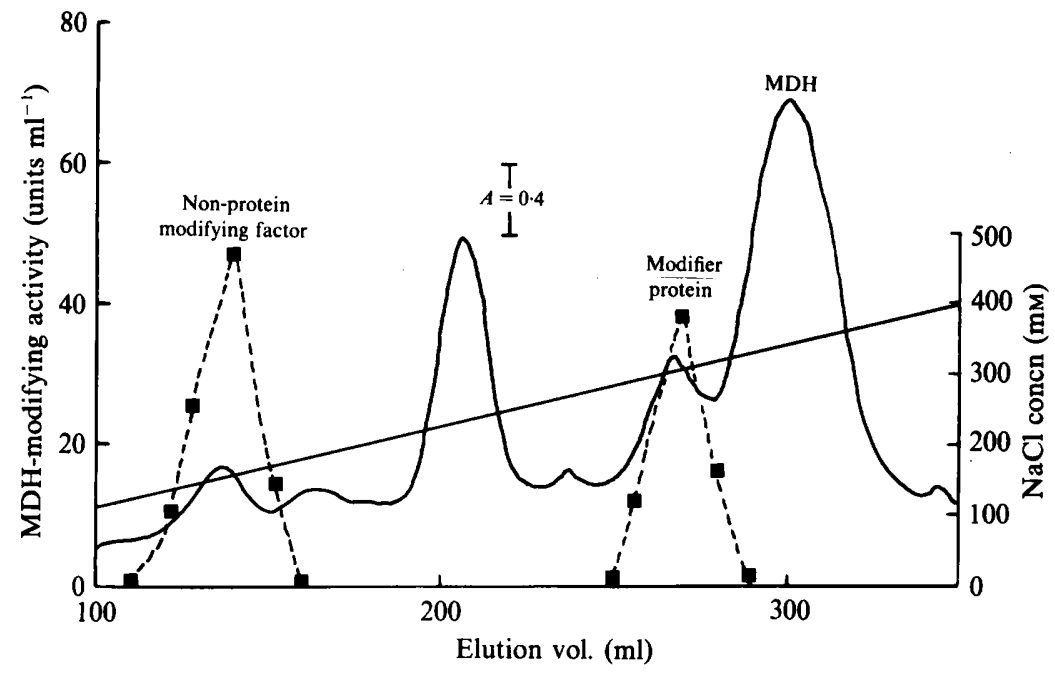

Fig. 2. Separation of MDH and two modifying factors by ion-exchange chromatography of periplasmic proteins of $P$. denitrificans. Periplasmic protein $(100 \mathrm{mg})$ from aerobic, methanol-grown bacteria was applied to a column of DEAE-Sepharose equilibrated in $20 \mathrm{mM}$-HEPES buffer ( $\mathrm{pH} 7 \cdot 5$ ). Protein was eluted with a linear gradient of $\mathrm{NaCl}\left(1.2 \mathrm{mM} \mathrm{ml}^{-1}\right)$ in the same buffer (represented by a solid, sloping line). The solid curve represents protein, measured by its absorbance at $280 \mathrm{~nm}$ (the vertical bar represents an absorbance of 0.4 at this wavelength). Each fraction was assayed for MDH activity and for M-protein activity with butane-1,3-diol as substrate ( $\square$ ).

\section{Table 3. Partial purification of $M$-protein from $P$. denitrificans}

$\mathrm{M}$-protein was purified from $2 \mathrm{~g}$ periplasmic protein prepared from aerobic, methanol-grown bacteria as described in Methods. Because of the presence of a second stimulatory factor in the periplasmic fractions it is not possible to express purification factors and yields in terms of the initial activity. The values in this Table cannot be compared directly with those published for other bacteria because in other cases the starting material was total soluble extract, rather than periplasmic fractions. Units are defined in the Methods section. Specific activities are units (mg protein) ${ }^{-1}$.

\begin{tabular}{lcccccc}
\hline \hline $\begin{array}{l}\text { Purification } \\
\text { stage }\end{array}$ & $\begin{array}{c}\text { Vol. } \\
(\mathrm{ml})\end{array}$ & $\begin{array}{c}\text { Total } \\
\text { units }\end{array}$ & $\begin{array}{c}\text { Total } \\
\text { protein } \\
(\mathrm{mg})\end{array}$ & $\begin{array}{c}\text { Specific } \\
\text { activity }\end{array}$ & $\begin{array}{c}\text { Purifi- } \\
\text { cation } \\
\text { factor }\end{array}$ & $\begin{array}{c}\text { Yield } \\
\text { (\%) }\end{array}$ \\
\hline $\begin{array}{l}\text { DEAE-Sepharose } \\
\text { Sephacryl-200 }\end{array}$ & 120 & 6000 & 160 & $37 \cdot 5$ & 1 & 100 \\
Mono-Q & 63 & 2016 & 27 & 75 & 2 & 34 \\
\hline \hline
\end{tabular}

was necessary to purify and characterize the putative Mprotein from the periplasmic fractions.

Purification and characterizatioan of a non-protein, $M D H$-modifying factor from P. denitrificans. Fig. 2 shows the separation of two periplasmic MDH-modifying factors by anion-exchange chromatography. These were demonstrated by their ability to stimulate the continuous oxidation of butane-1,3-diol by pure $\mathrm{MDH}$; in the absence of the modifying factors pure MDH catalysed only a brief transient oxidation of this substrate as previously shown for MDHs of other bacteria (Page \& Anthony, 1986).

The first factor to be eluted (just prior to cytochrome $c_{550}$ ) was not retained by an Amicon PM-10 ultrafiltration membrane (mol. mass cut-off $10 \mathrm{kDa}$ ) but could be concentrated using a Millipore ultrafiltration membrane (mol. mass cut-off $1 \mathrm{kDa}$ ). This factor was purified further by anion-exchange chromatography in $20 \mathrm{mM}$ HEPES buffer ( $\mathrm{pH}$ 7.5) on a Pharmacia Mono-Q column, eluting at $150 \mathrm{~mm}-\mathrm{NaCl}$. There was no protein present in the active fractions, which showed an absorption maximum at $254 \mathrm{~nm}$. It was stable between $\mathrm{pH} 2$ and pH 11 and to heating for $10 \mathrm{~min}$ at $100{ }^{\circ} \mathrm{C}$. In the dye-linked assay it promoted a continuous oxidation by MDH of butane-1,3-diol but had very little effect on the oxidation of formaldehyde and no effect on methanol oxidation. This small, stable, non-protein stimulatory factor was similar in all respects to that demonstrated in extracts of organism 4025 (above).

Purification and characterization of the M-protein from $P$. denitrificans. During anion-exchange chromatography of the periplasmic fraction of $P$. denitrificans, the second peak of active material from the DEAE-Sepharose column (Fig: 2) eluted immediately prior to the MDH. This was a typical M-protein (able to inhibit formaldehyde oxidation by $\mathrm{MDH}$ ) and so was purified from periplasmic fractions on a large scale as described in Methods, and summarized in Table 3. 


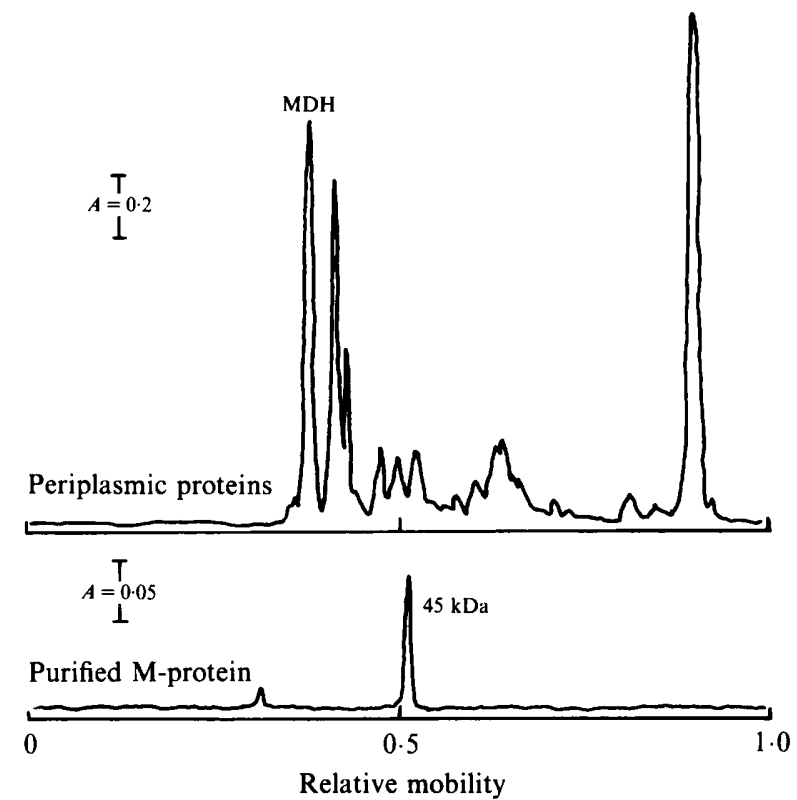

Fig. 3. SDS-PAGE analysis of periplasmic proteins and partially purified M-protein of $P$. denitrificans. Gels were stained and scanned as described in Methods. Absorbance was recorded at $626 \mathrm{~nm}$ (indicated by the vertical bars). The gels represented here were adjacent gel lanes after electrophoresis in a Bio-Rad Mini-gel system. It should be noted that the $45 \mathrm{kDa}$ peak in the gel of the purified fraction does not align perfectly with any peak in the gel of the periplasmic fraction.

The M-protein was very sensitive to buffer composition, as found for the M-protein from M. methylotrophus (Page \& Anthony, 1986). HEPES buffer (20 mM, $\mathrm{pH} 7.5$ ) was the only buffer able to maintain activity; it was used in all purification procedures and the protein was stored without loss of activity at $-17^{\circ} \mathrm{C}$ in this buffer. Samples frozen in MOPS, phosphate or Tris were found to have lost all activity on thawing. All activity was destroyed by protamine sulphate or by ammonium sulphate which precluded its use for purification by protein precipitation or hydrophobic-interaction chromatography. Fig. 3 shows a scan of a gel after SDSPAGE of the periplasmic fraction and of the purified Mprotein. The major band in the gel of the purified protein was a $45 \mathrm{kDa}$ polypeptide as was found (this paper) for the partially purified M-protein from organism 4025 and $M$. methylotrophus. If this represents the M-protein then consideration of the gel of the periplasmic fraction suggests that the ratio of the amount of M-protein to MDH is much less than $1: 5$.

Analytical gel filtration on Pharmacia Superose-12 or Sephacryl S-200 indicated that the native molecular mass of M-protein is about $135 \mathrm{kDa}$, suggesting that the $\mathrm{M}$ protein is multimeric (probably a trimer or tetramer). The isoelectric point (pI) of the protein was about 4 as indicated by its elution from anion-exchange columns between MDH (pI 3.7) and cytochrome $c_{550}$ (pI 4.5).

As observed for M-proteins of other bacteria this M- protein stimulated the initial rate of oxidation of butane1,3-diol by increasing its affinity for MDH. It inhibited formaldehyde oxidation in the dye-linked assay by increasing its affinity for $\mathrm{MDH}$, the $K_{\mathrm{m}}$ increasing from $0.1 \mathrm{~mm}$ to $0.48 \mathrm{~mm}$.

Activity of the M-protein of $P$. denitrificans in the cytochrome-linked reaction. The physiological electron acceptor for $\mathrm{MDH}$ in $\boldsymbol{P}$. denitrificans is a specific cytochrome $c$ called cytochrome $c_{552}$, which is a $22 \mathrm{kDa}$, acidic, periplasmic cytochrome corresponding to cytochrome $c_{\mathrm{L}}$ in other methylotrophs (Long \& Anthony, 1991). In an assay system using methanol as substrate and cytochrome $c_{552}$ as electron acceptor (BeardmoreGray et al., 1983) the rate of formaldehyde accumulation was $0.22 \mathrm{nmol} \mathrm{min}{ }^{-1}(\mathrm{nmol} \mathrm{MDH})^{-1}$, and the rate of reduction of the single electron acceptor cytochrome $c$ was $0.73 \mathrm{nmol} \mathrm{min} \mathrm{mol}^{-1}(\mathrm{nmol} \mathrm{MDH})^{-1}$ instead of the expected $0.44 \mathrm{nmol} \mathrm{min}^{-1}$, suggesting, as shown for other MDHs, that some of the formaldehyde produced during methanol oxidation was being oxidized to formate with concomitant reduction of the cytochrome $c$. The rate of oxidation of formaldehyde when it was the sole substrate was similar to that for methanol, and in this case the rate of reduction of cytochrome $c$ (being a single electron carrier) was exactly twice this value. In the presence of M-protein $(0.4 \mu \mathrm{M})$ with methanol as substrate, the rates of formaldehyde production and cytochrome reduction decreased, and the ratio of cytochrome reduced to formaldehyde produced decreased to about 2 . This suggests that $\mathrm{M}$-protein was partially inhibiting methanol oxidation and diminishing formaldehyde oxidation to a negligible rate. In the same system, with $2 \mu \mathrm{M}-\mathrm{MDH}$ and formaldehyde $(100 \mu \mathrm{M})$ as substrate, oxidation was inhibited $50 \%$ by $0.4 \mu \mathrm{M}$-M-protein.

The effect of M-protein on the kinetics of MDH activity with cytochrome $c_{552}$ was determined in a modification of the cytochrome-linked assay system that permits use of smaller amounts of material (Day \& Anthony, 1990). In the absence of M-protein, the $K_{\mathrm{m}}$ for methanol in this system was $15 \mu \mathrm{M}$. M-protein decreased the initial rates of methanol oxidation and increased the affinity for methanol, the maximum effect occurring when the molar ratio of MDH :M-protein was $5: 1$ (Fig. 4). The $V_{\max }$ decreased to about $45 \%$ of the uninhibited value and the $K_{\mathrm{m}}$ value decreased from $15 \mu \mathrm{M}$ to $11 \mu \mathrm{M}$. With formaldehyde as substrate, the maximum effect of M-protein also occurred when the ratio of MDH:Mprotein was $5: 1$ (Fig. 5). In this case, the $V_{\max }$ decreased (as with methanol), but the affinity of $\mathrm{MDH}$ for its substrate decreased. The $V_{\max }$ decreased to about $45 \%$ (as with methanol) and the $K_{\mathrm{m}}$ value increased from $0.1 \mathrm{mM}$ to $0.36 \mathrm{mM}$. Above this concentration of $\mathrm{M}$ protein there was no further increase in $K_{\mathrm{m}}$ value. 


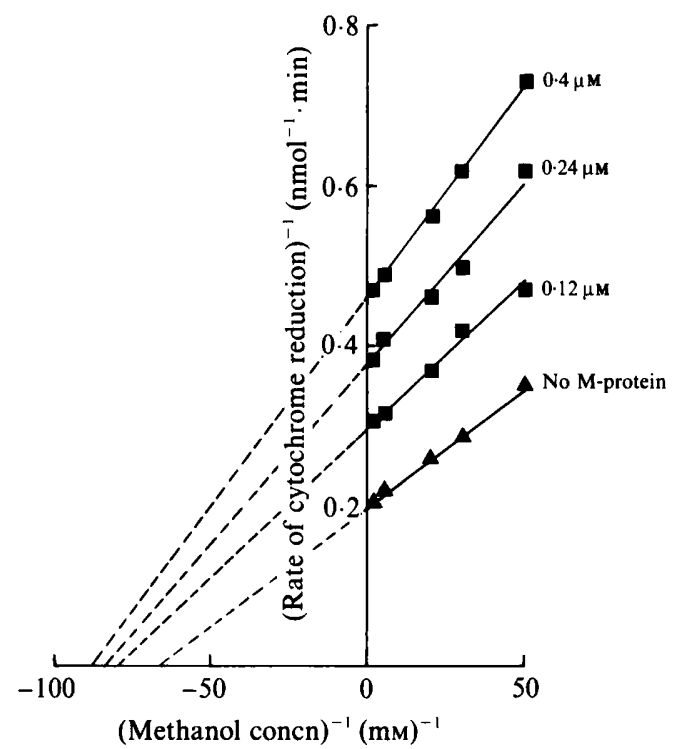

Fig. 4

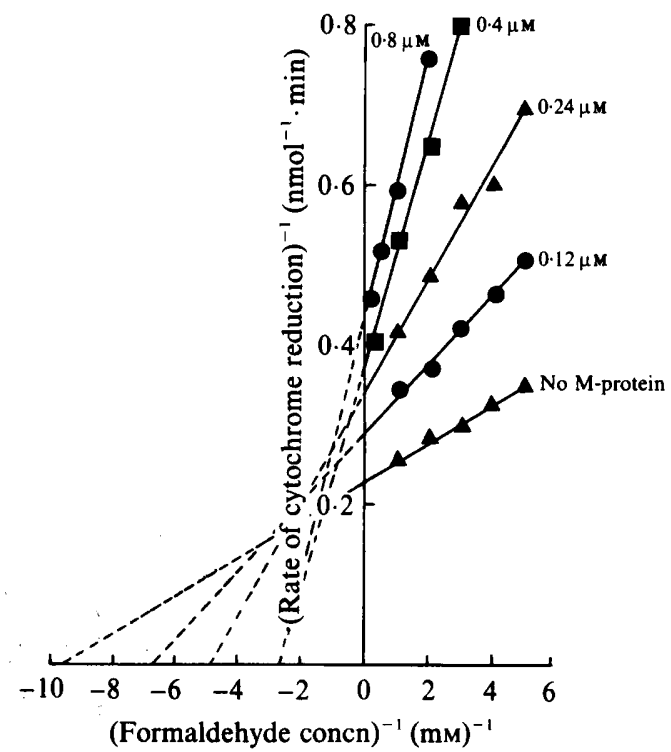

Fig. 5

Fig. 4. Effect of $\mathrm{M}$-protein on the methanol :cytochrome $c_{\mathrm{L}}$ oxidoreductase activity of MDH of $\boldsymbol{P}$. denitrificans. Reaction mixtures contained pure MDH $(2 \mu \mathrm{M})$, cytochrome $c_{552}(10 \mu \mathrm{M})$ and horse heart cytochrome $c(500 \mu \mathrm{M})$. Rates were measured over a range of methanol concentrations and amounts of $\mathrm{M}$-protein $(0-0.8 \mu \mathrm{M}-\mathrm{M}$-protein). The rates measured with $0.8 \mu \mathrm{M}$ protein were almost indistinguishable from those measured with $0 \cdot 4 \mu \mathrm{M}$.

Fig. 5. Effect of M-protein on the formaldehyde : cytochrome $c_{\mathrm{L}}$ oxidoreductase activity of MDH of $P$. denitrificans. Reaction mixtures contained pure MDH $(2 \mu \mathrm{M})$, cytochrome $c_{552}(10 \mu \mathrm{M})$ and horse heart cytochrome $c(500 \mu \mathrm{M})$. Rates were measured over a range of formaldehyde concentrations and amounts of $\mathrm{M}$-protein ( $0-0.8 \mu \mathrm{M}-\mathrm{M}$-protein).

\section{Discussion}

The results described in this paper are all consistent with the conclusion that the protein previously identified in Methylobacterium extorquens AM1 and Methylophilus methylotrophus as the M-protein, having $67 \mathrm{kDa}$ subunits, was not the M-protein, but was a contaminant in the fractions containing the $M$-protein. This was first indicated by the lack of correlation between the extent of M-protein activity and amounts of $67 \mathrm{kDa}$ protein in sonic extracts of bacteria grown under a variety of conditions in continuous culture. It was confirmed in two different methylotrophs by separating the M-protein activity from the $67 \mathrm{kDa}$ protein by modifying the protein purification procedures. The M-protein activity was associated with a protein of about $135 \mathrm{kDa}$ having a subunit molecular mass of $45 \mathrm{kDa}$, and not with the protein having $67 \mathrm{kDa}$ subunits. Finally, the $67 \mathrm{kDa}$ protein was not present in periplasmic fractions whereas, in both methylotrophs tested, the M-protein was located exclusively in the periplasm. This is an especially significant conclusion in the context of a physiological function for the M-protein; clearly it needs to be in the periplasm if it indeed functions in the regulation of the periplasmic MDH.
It has been shown previously that the concentration of $\mathrm{MDH}$ in $\boldsymbol{M}$. methylotrophus decreases with increasing growth rate (Greenwood \& Jones, 1986), and the same was shown in this work to be true for M-protein activity. However, too much weight should not be given to this observation because of the complication of the presence of a non-protein factor, also present in some extracts, which is also able to stimulate the oxidation of the usual test substrate, butane-1,3-diol.

In addition to its periplasmic location, a second important conclusion of this work in relation to the proposed physiological function of the M-protein is the demonstration that it is effective in regulating the reaction of $\mathrm{MDH}$ with its periplasmic cytochome $c$ electron acceptor. The effect of $M$-protein on the cytochrome-linked activity of MDH of $P$. denitrificans differed slightly from that previously described for $M$. methylotrophus. In preliminary measurements with this obligate methylotroph the presence of M-protein led to a $50 \%$ increase in the oxidation rate for methanol. By contrast, in $\boldsymbol{P}$. denitrificans, $\mathbf{M}$-protein decreased the maximum rate with methanol by about $50 \%$, while increasing affinity of this substrate for MDH. More importantly, the effects of M-protein on the MDHs from the two bacteria were identical with respect to formalde- 
hyde oxidation; both the maximum rate $\left(V_{\max }\right)$ was decreased, and the affinity of the MDH for formaldehyde was decreased. The ratio of $\mathrm{MDH}: \mathrm{M}$-protein required for the maximum effect on $V_{\max }$ and $K_{\mathrm{m}}$ for both substrates was the same $(5: 1)$. This supports the previous proposal that $\mathrm{M}$-protein might have a role in preventing wasteful oxidation of formaldehyde by the methanol dehydrogenase in all methylotrophs. If this is the case then it is important to consider whether or not there is sufficient $\mathbf{M}$-protein present in the periplasm to have an effect in vivo. Gel scans of periplasmic fractions before purification of the M-protein showed no protein band corresponding to the $45 \mathrm{kDa}$ polypeptide that was the predominant band seen after SDS-PAGE of the partially purified M-protein. The proportion of $\mathrm{M}$-protein to $\mathrm{MDH}$ in the periplasmic fraction was well below the optimum proportion of $1: 5$ required in vitro for the maximum effect in diminishing the affinity of MDH for formaldehyde. It is probable that the only approach to resolving this question is by isolating mutants of $P$. denitrificans which are unable to synthesize M-protein and to test whether or not such mutants are altered with respect to ability to grow on methanol or with respect to growth rates and growth yields on this substrate. That no methanol ${ }^{-}$mutants have been isolated previously that lack M-protein suggests, perhaps, that lack of the protein may not be lethal on methanol but might merely have an effect on efficiency of growth in a competitive environment.

A second point of interest that remains, regardless of the physiological function of the M-protein, is the mechanism by which one protein is able to affect the activity of a second which is present in at least a fivefold excess.

We should like to thank the SERC for a research studentship for A.R.L.

\section{References}

Alefounder, P. R. \& Ferguson, S. J. (1981). A periplasmic location for methanol dehydrogenase from Paracoccus denitrificans: implications for proton pumping by cytochrome $a a_{3}$. Biochemical and Biophysical Research Communications 98, 778-783.

ANTHONY, C. (1982). The Biochemistry of Methylotrophs. London: Academic Press.

ANTHONY, C. (1986). The bacterial oxidation of methane and methanol. Advances in Microbial Physiology 27, 113-210.

ANTHONY, C. (1988). Quinoproteins and energy transduction. In Bacterial Energy Transduction, pp. 293-316. Edited by C. Anthony. London: Academic Press.
ANTHONY, C. (1990). The oxidation of methanol in Gram-negative bacteria. FEMS Microbiology Reviews 87, 209-214.

ANTHONY, C. \& ZatMan, L. J. (1967). The microbial oxidation of methanol: purification and properties of the alcohol dehydrogenase of Pseudomonas sp. M27. Biochemical Journal 104, 953-959.

AUTON, K. A. \& ANTHONY, C. (1989). The role of cytochromes and blue copper proteins in growth of an obligate methylotroph on methanol and methylamine. Journal of General Microbiology 135, 1923-1931.

BeARDMORE-Gray, M., O'KeEFFE, D. T. \& ANTHONY, C. (1983). The methanol :cytochrome $c$ oxidoreductase activity of methylotrophs. Journal of General Microbiology 129, 923-933.

Bolbot, J. A. \& ANThony, C. (1980). The metabolism of 1,2propanediol by the facultative methylotroph Pseudomonas AM1. Journal of General Microbiology 120, 245-254.

BRADFORD, M. (1976). A rapid and sensitive method for the quantitation of microgram quantities of protein utilizing the principle of protein-dye binding. Analytical Biochemistry 72, 248-254.

Chan, H. T. C. \& Anthony, C. (1991). The o-type oxidase of the acidophilic methylotroph Acetobacter methanolicus. Journal of General Microbiology 137, 693-704.

Cross, A. R. \& ANTHONY, C. (1980a). The purification and properties of the soluble cytochromes $c$ of the obligate methylotroph Methylophilus methylotrophus. Biochemical Journal 192, 421-427.

CROSs, A. R. \& ANTHONY, C. $(1980 b)$. The electron transport chains of the obligate methylotroph, Methylophilus methylotrophus. Biochemical Journal 192, 429-439.

DAY, D. J. \& ANTHONY, C. (1990). Methanol dehydrogenase from Methylobacterium extorquens AM1. Methods in Enzymology 188, 210-216.

DAY, D. J., NunN, D. N. \& ANTHONY, C. (1990). Characterization of a novel soluble $c$-type cytochrome in a moxD mutant of Methylobacterium extorquens AM1. Journal of General Microbiology 136, 181-188.

Ford, S., PAGE, M. D. \& ANTHONY, C. (1985). The role of methanol dehydrogenase modifier protein and aldehyde dehydrogenase in the growth of Pseudomonas AM1 on 1,2-propanediol. Journal of General Microbiology 131, 2173-2182.

GREENWOOD, J. A. \& JoNES, C. W. (1986). Environmental regulation of the methanol oxidase system of Methylophilus methylotrophus. Journal of General Microbiology 132, 1247-1256.

Jones, C. W., Kingsbury, S. A. \& Dawson, M. J. (1982). The partial resolution and dye-mediated reconstitution of methanol oxidase activity in Methylophilus methylotrophus. FEMS Microbiology Letters 13, 195-200.

LAwTON, S. A. \& ANTHONY, C. (1985). The roles of cytochromes and blue copper proteins in the oxidation of methanol and methylamine in organism 4025, an obligate methylotroph. Journal of General Microbiology 131, 2165-2171.

LONG, A. R. \& ANTHONY, C. (1991). Characterization of the periplasmic cytochromes $c$ of Paracoccus denitrificans: identification of the electron acceptor for methanol dehydrogenase, and description of a novel cytochrome $c$ heterodimer. Journal of General Microbiology 137, 415-425.

PAGE, M. D. \& ANTHONY, C. (1986). Regulation of formaldehyde oxidation by the methanol dehydrogenase modifier-proteins of Methylophilus methylotrophus and Pseudomonas AM1. Journal of General Microbiology 132, 1553-1563.

Walker, J. E., Auffret, D., Carne, A., Gurnett, A., Hanish, P., HILL, D. \& SARASTE, M. (1982). Solid-phase sequence analysis of polypeptides eluted from polyacrylamide gels. An aid to interpretation of DNA sequences exemplified by the Escherichia coli anc operon and bacteriophage lambda. European Journal of Biochemistry 123, 253-260. 